\title{
Corrosion Mechanism of Corrosion-Resistant Steel Developed for Bottom Plate of Cargo Oil Tanks
}

\author{
Feilong $S U N^{1)}$, Xiaogang $L I^{1,2)}$, Fan $Z H A N G^{1)}$, Xuequn $C H E N G^{1,2) \dagger}$, Cheng ZHOU ${ }^{3)}$, \\ Nianchun $\left.W U^{4}\right)$, Yuqun $Y^{4}{ }^{4}$ and Jinbin $\mathrm{ZHAO}^{4}$ \\ 1) Corrosion and Protection Center, University of Science and Technology Beijing, Beijing 100083, China \\ 2) Key Laboratory of Corrosion and Protection, Ministry of Education, Beijing 100083, China \\ 3) School of Materials Science and Engineering, University of Science and Technology Beijing, Beijing 100083, China \\ 4) Research Institute, Nanjing Iron \& Steel Co., LTD., Nanjing 210035, China \\ [Manuscript received 30 November 2012, in revised form 4 February 2013] \\ (c) The Chinese Society for Metals and Springer-Verlag Berlin Heidelberg
}

\begin{abstract}
A new type of corrosion-resistant steel consisting of ferrite and bainite phases was developed for cargo oil tanks of crude oil tankers. The corrosion rate of this new steel was $0.22 \mathrm{~mm} / \mathrm{a}$, which was equivalent to ca. $1 / 5$ of the criterion ( $\leq 1 \mathrm{~mm} / \mathrm{a}$ ) for corrosion-resistant steels. The composition and element distribution of the corrosion products were investigated by micro-Raman spectrometry and energy dispersive spectrometer. The results demonstrated that the corrosion product was composed of $\alpha-\mathrm{FeOOH}, \mathrm{Fe}_{3} \mathrm{O}_{4}$ and a continuous $\mathrm{Cu}$ enrichment layer. This kind of corrosion product was protective to the steel matrix and accounted for the enhancement of the corrosion resistance of the new developed steel.
\end{abstract}

KEY WORDS: Alloying elements; Corrosion; Low alloy steel; Raman spectroscopy; SEM

\section{Introduction}

Oil tanker accidents, which occurred frequently in the last decades, had led to massive oil leakage. These oil leakage disasters not only endangered the natural life, but also caused an enormous economic loss. It is usually related to material degradation caused or influenced by undetected corrosion ${ }^{[1]}$. Among which, the corrosion problem of the cargo oil tanks (COT) of crude oil tankers is quite severe. At the COT, the inner bottom plate is covered by oil layer containing sludge, drain water including highly concentrated $\mathrm{Cl}^{-}$ and $\mathrm{H}_{2} \mathrm{~S}$ originating from the crude oil. In general, this kind of oil layer could decrease the corrosion rate of the bottom plate. However, local defects would occur in the oil layer by crude oil washing. Then the inner bottom plate is exposed to the severe corrosion environment with concentrated $\mathrm{Cl}^{-}$and $\mathrm{H}_{2} \mathrm{~S}$. As a

\footnotetext{
† Corresponding author. Assoc. Prof., Ph.D.; Tel: +86 10 62333931; Fax:+86 10 62334005; E-mail address: chengxuequn@ustb.edu.cn (Xuequn CHENG)
}

DOI: $10.1007 / \mathrm{s} 40195-012-0231-0$ result, pits would originate from these defects and grow by forming galvanic cell between the defect (anode) and steel surface beneath the oil layer around defect (cathode) ${ }^{[2-4]}$. Intensive investigations have been carried out on pitting corrosion phenomena on inner bottom plates of COT of Very Large Crude Carrier (VLCC). Based on above studies, some key facts for inner bottom plate corrosion are summarized ${ }^{[2,5-9]}$ : (1) The solution is neutral brine (not sea water), which contains 10 wt.\% NaCl; (2) In pits, $\mathrm{pH}$ value of the solution is lower than 1.5 ; (3) The majority of pits at the bottom plate are of bowl shape; (4) In some cases, the pitting corrosion rate reaches $4 \mathrm{~mm} / \mathrm{a}$; (5) The pit growth stops at dock inspection.

Coating is one of the well-known corrosion prevention methods, which isolates the steel surface from corrosion environments. If the coating was applied completely, the isolation effect would be perfect. However, intact coating working without defect would be very difficult from initial surface preparation to the final coating. In general, very tiny defects existed in the coating layer. Moreover, once the coating was removed from conventional steel, the substrate would 
be exposed to corrosion environment. The growth of pitting corrosion would start at high rate, and the risk of perforation of the bottom plate is high, that would lead to crude oil leakage. It was investigated that a lot of bowl-shaped pits $4 \mathrm{~mm}$ or more in depth occurred on the inner bottom of $\mathrm{COT}^{[2]}$, which needed inspection and repair of every dock with high economic and labor costs. If the pitting was not detected and repaired, the bottom plate will be confronted with high risk of perforation. Therefore, the development of corrosion-resistant steel which lowered risk of perforation of the inner bottom plates is important. In this respect, such work had been started by Japanese scholars from $2002^{[4,6-9]}$, in which micro-alloying was used as the manufacturing approach. These steels had high corrosion resistance compared with conventional steels, with $1 / 5-1 / 2$ corrosion rate of conventional steels. In recent years, Chinese scholars began to research and develop corrosion-resistant steel for COT. They investigated the effects of composition and microstructure on corrosion properties of corrosion-resistant steel and welded joint ${ }^{[10-12]}$. However, the corrosion mechanism of micro-alloying steel is far from clear and needs further research.

The current work is devoted to investigating the effect of alloy elements on the corrosion properties of the self-developed corrosion-resistant steel for COT. Its microstructure and corrosion behavior were studied by SEM, potentiodynamic polarization curves and EIS techniques. And then the composition of the rust layer was analyzed mainly using micro-Raman spectrometry and energy dispersive spectrometer (EDS), which could give us insight into corrosion mechanism of the self-developed steel. Furthermore, the understanding of the corrosion behavior and mechanism of micro-alloying steel will be improved, which is helpful for the development of the new corrosion-resistant steel for COT of crude oil tankers.

\section{Experimental Procedures}

\subsection{Preparation of specimens and solution}

The specimens were made of A36 ship plate steel selected as conventional steel according to IMO MSC 87/26/Add. 1 Annex 3 MSC. 289 (87) ${ }^{[13]}$, and the self-developed corrosion-resistant steel for COT. The compositions of A36 and the self-developed steels are listed in Table 1. It was shown that the self-developed steel had lower content of $\mathrm{C}$ and $\mathrm{P}$ and higher content of alloying elements, such as $\mathrm{Cu}, \mathrm{Ni}$ and $\mathrm{Mo}$, in comparison to A36 steel. The self-developed steel was manufactured by Thermo-Mechanical Control Processing (TMCP) at a cooling rate of $15^{\circ} \mathrm{C} / \mathrm{s}$. Its yield strength $\sigma_{\mathrm{s}}$ and tensile strength $\sigma_{\mathrm{b}}$ were $485 \mathrm{MPa}$ and $545 \mathrm{MPa}$, respectively. The impact energy $A_{\mathrm{K}}$ at $-40{ }^{\circ} \mathrm{C}$ reached $298 \mathrm{~J}$. The samples for immersion tests were cut into $60 \mathrm{~mm} \times 25 \mathrm{~mm} \times 5 \mathrm{~mm}$, and then drilled hole with $\phi 3 \mathrm{~mm}$ for suspension. The longitudinal direction of samples was parallel to the rolling direction of steels. The samples for electrochemical tests were cut into $10 \mathrm{~mm} \times 10 \mathrm{~mm} \times 5 \mathrm{~mm}$, and then embedded with epoxy resin leaving a working area of $1 \mathrm{~cm}^{2}$. Prior to experiments, the specimens were abraded with waterproof abrasive paper down to 2000 grit and finally polished with $1.5 \mu \mathrm{m} \mathrm{Al}_{2} \mathrm{O}_{3}$ powder.

All experiments were performed in $10 \mathrm{wt} . \% \mathrm{NaCl}$ solution with $\mathrm{pH}$ value of 0.85 at $(30 \pm 2){ }^{\circ} \mathrm{C}$. The solutions were prepared with analytical pure reagents and distilled water. The $\mathrm{pH}$ value of the solution was adjusted using concentrated hydrochloric acid.

\subsection{Immersion experiments}

The immersion experiments were carried out according to IMO MSC 87/26/Add. 1 Annex 3 MSC. 289 (87), the performance standards for alternative means of corrosion protection for cargo oil tanks of crude oil tankers, in order to simulate corrosion environment of ship plate steels equipped at flat inner bottom of $\mathrm{COT}^{[13]}$. Five parallel specimens were used to perform each immersion experiment, which was carried out for $72 \mathrm{~h}$. The corrosion mass loss rate was used to evaluate corrosion resistance of specimens.

The decaling liquid was hydrochloric acid solution $(50$ vol. $\%)+3.5 \mathrm{~g} / \mathrm{L}\left(\mathrm{CH}_{2}\right)_{6} \mathrm{~N}_{4}$.

\subsection{Electrochemical experiments}

Electrochemical experiments were carried out in a three-electrode cell. The counter and reference electrode were $\mathrm{Pt}$ sheet and saturated calomel electrode (SCE), respectively. The working electrode was made of A36 steel or the self-developed steel.

The potentiodynamic polarization measurements were performed using an electrochemical workstation (PARSTAT 2273) with a potential scan rate of $0.333 \mathrm{mV} / \mathrm{s}$. The EIS measurements were also carried out on the workstation too. The scanning frequency ranged from $100 \mathrm{kHz}$ to $10 \mathrm{mHz}$ and the perturbing $\mathrm{AC}$ amplitude was $5 \mathrm{mV}$. The reproducibility of the presented data was double checked by multiple measurements and typical results were reported.

\subsection{Microstructure observation}

The microstructures of A36 and self-developed steels were observed by SEM (FEI Quanta 250) after etching in $4 \%$ Nital. The composition of the rust layer on samples after immersion tests was detected

Table 1 Composition (wt.\%) of A36 and the self-developed steels

\begin{tabular}{ccccccccccc}
\hline Specimen & $\mathrm{C}$ & $\mathrm{Si}$ & $\mathrm{Mn}$ & $\mathrm{P}$ & $\mathrm{S}$ & $\mathrm{Al}$ & $\mathrm{Cu}$ & $\mathrm{Ni}$ & $\mathrm{Mo}$ & $\mathrm{Fe}$ \\
\hline A36 steel & 0.16 & 0.20 & 1.17 & 0.022 & 0.008 & 0.030 & 0.006 & 0.02 & 0.008 & Bal. \\
Self-developed steel & 0.08 & 0.30 & 1.46 & $\leq 0.010$ & $\leq 0.010$ & 0.030 & 0.50 & 0.10 & 0.02 & Bal. \\
\hline
\end{tabular}


by EDS and micro-Raman spectrometry. Raman spectroscopy observation was undertaken using a JYHR800 Confocal Microprobe Raman Spectrometer with an exciting wavelength of $532 \mathrm{~nm}$ from the light source of an argon ion laser. Low laser power was used for the reference spectra to minimize the risks of spectral changes due to sample degradation ${ }^{[14,15]}$. Excitation laser power on the samples was filtered to $0.1 \mathrm{~mW}$ to avoid thermal effects on the sensitive iron oxides and oxy-hydroxides.

\section{Results}

\subsection{Microstructure analysis}

The metallographic structure of A36 and selfdeveloped steels are shown in Fig. 1. It demonstrates that the microstructure of A36 steel consists of ferrite phase and pearlite $(\mathrm{F} / \mathrm{P})$. The grain size is about 10 $30 \mu \mathrm{m}$ measured by a line intercept method. The microstructure of self-developed steel is composed of ferrite phase and bainite $(\mathrm{F} / \mathrm{B})$. The grain size is about $5-18 \mu \mathrm{m}$. The average grain size of self-developed steel is smaller than that of A36 steel, which can be attributed to its faster cooling rate $\left(15^{\circ} \mathrm{C} / \mathrm{s}\right)$. The existence of pearlite reduces the corrosion resistance of A36 steel due to the lamellar structure of ferrite and cementite in pearlite ${ }^{[16]}$.

\subsection{Corrosion rate analysis}

The corrosion mass loss rate can be calculated by the following equation ${ }^{[13]}$ :

$$
v=\frac{8.76 \times 10^{4} \times W}{S \times t \times \rho}
$$

where $v$ is the corrosion mass loss rate (mm/a); $W$ is the weight loss $(\mathrm{g}) ; S$ is the sample surface area $\left(\mathrm{cm}^{2}\right)$; $\rho$ is the metal density $\left(\mathrm{g} / \mathrm{cm}^{3}\right)$ and $t$ is the immersion time (h).

The average corrosion mass loss rates of A36 and self-developed steels are 1.31 and $0.22 \mathrm{~mm} / \mathrm{a}$, respectively. The corrosion mass loss rate of self-developed steel is merely about $1 / 6$ that of A36 steel. The accepted criterion for corrosion-resistant steel of COT is $v \leq 1 \mathrm{~mm} / \mathrm{a}$, according to IMO MSC $87 / 26 /$ Add. 1 Annex 3 MSC. 289 (87). The corrosion mass loss rate of self-developed steels is ca. $1 / 5$ of the accepted criterion. Moreover, this corrosion mass loss rate is lower than that of NSGP-1 as reported in literature [17]. Therefore, the self-developed steel can not only meet the requirement of COT on corrosion-resistant steel, but also has superior corrosion resistance compared with its counterpart.

Based on the obtained corrosion mass loss rate, the corrosion current density $i_{\text {corr }}$ can be calculated according to Faraday's law ${ }^{[18]}$ :

$$
i_{\text {corr }}=\frac{v \times z \times F \times \rho}{3.16 \times 10^{8} \times M}
$$

where $z$ is the number of electrons transferred per metal atom; $F$ is the Faraday's constant $(\mathrm{C} / \mathrm{mol}) ; M$ is the molar mass of the metal $(\mathrm{g} / \mathrm{mol})$.

Fig. 2 shows potentiodynamic polarization curves of A36 and the self-developed steels measured in 10 wt.\% $\mathrm{NaCl}$ solution at $(30 \pm 2){ }^{\circ} \mathrm{C}$. Typical active dissolution behavior could be recognized on both curves. The anodic and cathodic branches of the polarization curves of A36 and the self-developed specimens display Tafel behavior. Thus, Tafel extrapolation can be applied to calculate corrosion current density $i_{\text {corr }}$, anodic Tafel slope $\beta_{\mathrm{a}}$ and cathodic Tafel slope $\beta_{\mathrm{c}}$. The results are displayed in Table 2 .

Fig. 3 shows EIS results of A36 and the selfdeveloped steels measured in $10 \mathrm{wt} \% \mathrm{NaCl}$ solution at $(30 \pm 2){ }^{\circ} \mathrm{C}$, which are presented as Nyquist and Bode plots. It shows that one semicircle exists over the measured frequency range in EIS of A36 specimens. While two semicircles can be observed over the measured frequency range in EIS of the self-developed specimens: a high-frequency capacitive semicircle and a middle-frequency capacitive loop.

The equivalent electrical circuits shown in Fig. 4(a) and Fig. 4(b) were used to fit the impedance data of A36 and the self-developed specimens, respectively. Where $R_{\mathrm{s}}$ is the solution resistance, $C P E_{\mathrm{dl}}$ is the constant phase element which expresses the double

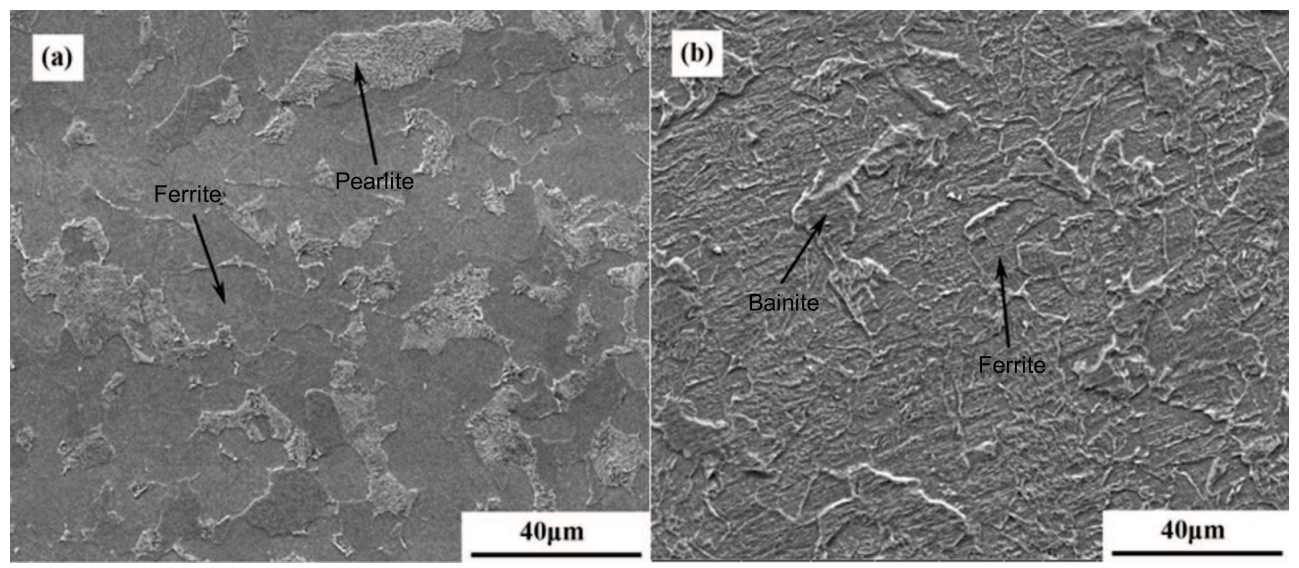

Fig. 1 SEM images of metallographic structure of A36 (a) and self-developed (b) steels 
layer capacitance and $R_{\mathrm{t}}$ expresses the charge transfer resistance of steel, $C P E_{\mathrm{f}}$ is the constant phase element which related to corrosion product film and $R_{\mathrm{f}}$ is corrosion product film resistance, respectively ${ }^{[19-21]}$. The $R_{\mathrm{t}}$ and $R_{\mathrm{f}}$ of the specimens can be obtained through the fitting with the equivalent electrical circuit, which are listed in Table 2 . Since $R_{\mathrm{P}}=\left(Z_{\mathrm{F}}\right)_{\omega=0}$, the polarization resistance $R_{\mathrm{P}}$ of

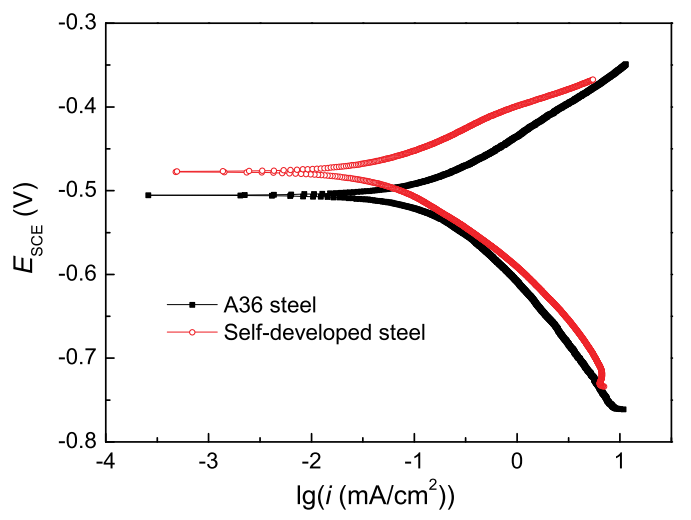

Fig. 2 Potentiodynamic polarization curves of A36 and self-developed steels in 10 wt.\% $\mathrm{NaCl}$ solution at $(30 \pm 2){ }^{\circ} \mathrm{C}$
A36 and the self-developed steels can be expressed as $R_{\mathrm{P}}=R_{\mathrm{t}}$ and $R_{\mathrm{P}}=R_{\mathrm{t}}+R_{\mathrm{f}}$ respectively. $R_{\mathrm{P}}$ is related to the corrosion current density $i_{\text {corr }}$ through the Tafel slopes $\beta_{\mathrm{a}}$ and $\beta_{\mathrm{c}}$ according to Stern-Geary equation $^{[22,23]}$ :

$$
i_{\text {corr }}=\frac{1}{2.303 R_{\mathrm{P}}\left(\frac{1}{\beta_{\mathrm{a}}}+\frac{1}{\left|\beta_{\mathrm{c}}\right|}\right)}
$$

The corrosion current densities $i_{\text {corr }}$ obtained by corrosion mass loss, Tafel extrapolation method and Stern-Geary equation are summarized in Fig. 5. It indicates that $i_{\text {corr }}$ obtained by immersion test, potentiodynamic polarization and EIS measurements are correlated with each other. The $i_{\text {corr }}$ of the selfdeveloped specimen is much less than that of A36 specimen, which means that the corrosion resistance of the self-developed steel was enhanced greatly.

\subsection{Composition of corrosion product}

Fig. 6 and Fig. 7 show the SEM images and EDS spectra of corrosion products of A36 and selfdeveloped steels after $240 \mathrm{~h}$ immersion test. It is demonstrated that there are non-metallic inclusions

Table 2 Fitting results of potentiodynamic polarization curves and EIS of A36 and the selfdeveloped steels

\begin{tabular}{ccccccc}
\hline specimen & $\begin{array}{c}E_{\text {corr }} \\
(\mathrm{V})\end{array}$ & $\begin{array}{c}i_{\text {corr }} \\
\left(10^{-5} \mathrm{~A} / \mathrm{cm}^{2}\right)\end{array}$ & $\beta_{\mathrm{a}}$ & $\beta_{\mathrm{c}}$ & $\begin{array}{c}R_{\mathrm{t}} \\
\left(\Omega \cdot \mathrm{cm}^{2}\right)\end{array}$ & $\begin{array}{c}R_{\mathrm{f}} \\
\left(\Omega \cdot \mathrm{cm}^{2}\right)\end{array}$ \\
\hline A36 steel & -0.506 & 15.3 & 0.078 & -0.136 & 159.0 & - \\
Self-developed steel & -0.478 & 4.9 & 0.042 & -0.106 & 644.1 & 9.3 \\
\hline
\end{tabular}
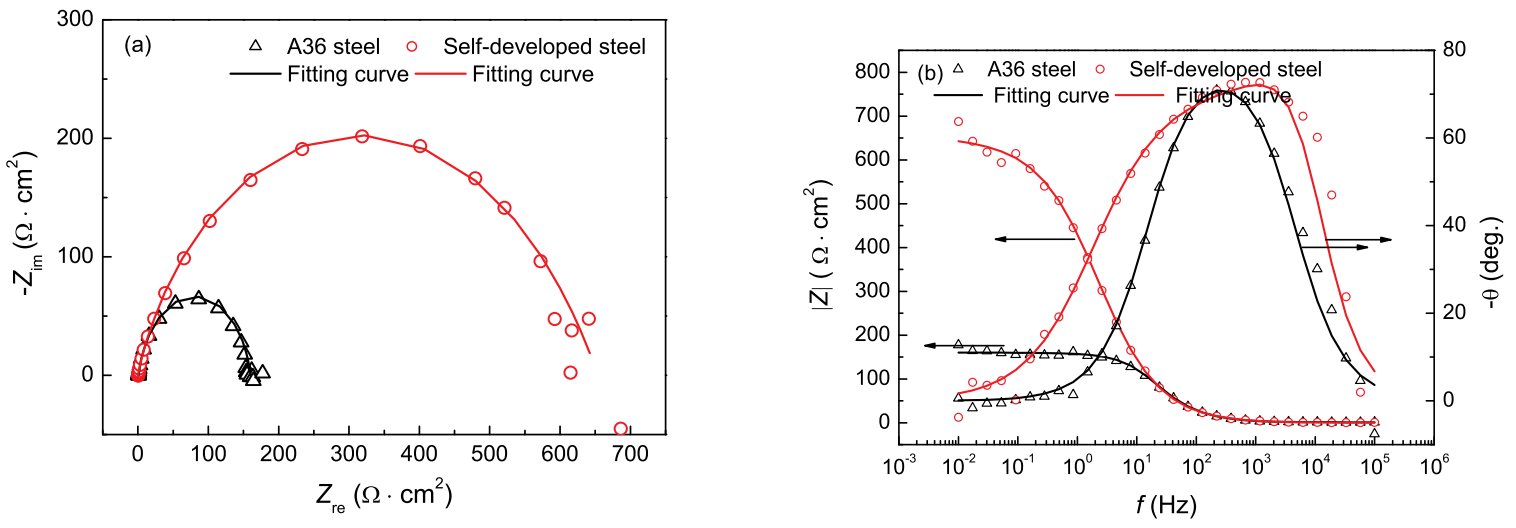

Fig. 3 The Nyquist plots (a) and Bode plots (b) of EIS of A36 and self-developed steels in 10 wt.\% $\mathrm{NaCl}$ solution at $(30 \pm 2){ }^{\circ} \mathrm{C}$
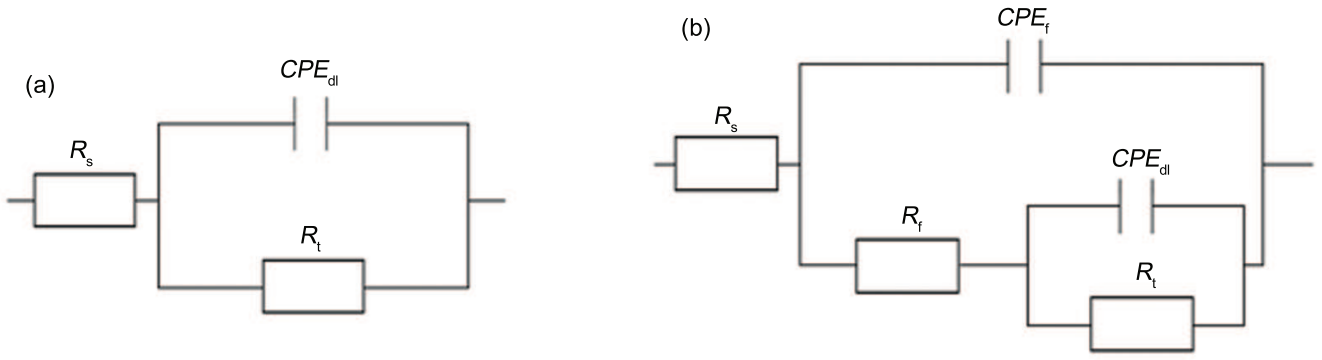

Fig. 4 The equivalent electrical circuit for EIS of A36 (a) and self-developed (b) steels in 10 wt.\% $\mathrm{NaCl}$ solution at $(30 \pm 2){ }^{\circ} \mathrm{C}$ 
in the research steels. The chemical compositions of corrosion product matrix and inclusions are shown in Table 3. Many kinds of metal elements (such as Fe, $\mathrm{Cu}$ and $\mathrm{Mn}$ ) and non-metallic elements (such as $\mathrm{O}$ and $\mathrm{Cl}$ ) exist in the corrosion products of A36 steel; while no $\mathrm{Cl}$ element is found in the corrosion products of the self-developed steel. This indicates that chloride ions might not participate in the formation of corrosion products of the self-developed steel. The

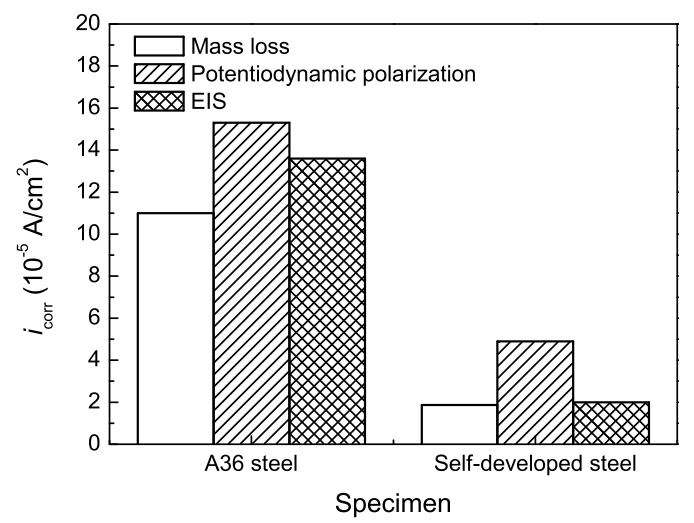

Fig. 5 Comparison of corrosion current density $i_{\text {corr }}$ according to mass loss test, potentiodynamic polarization and EIS measurements content of $\mathrm{Cu}$ in the corrosion products of the selfdeveloped steel is 23 at.\%, which is higher than that (3.8 at.\%) of A36. It also indicated that the better corrosion resistance of the self-developed steel might be attributed to the formation of copper oxide in the corrosion product.

Fig. 8 and Fig. 9 show SEM image and Xray elemental maps of corrosion product of A36 and the self-developed steel after $240 \mathrm{~h}$ immersion test in 10 wt. $\% \mathrm{NaCl}$ solution at $(30 \pm 2){ }^{\circ} \mathrm{C}$, respectively. It can be seen that the inclusions in both steels are composed of $\mathrm{O}, \mathrm{Al}$ and $\mathrm{Mg}$, which could be assigned to $\mathrm{MgO} \cdot \mathrm{Al}_{2} \mathrm{O}_{3}$. The element of $\mathrm{Cu}$ in the corrosion product matrix of A36 steel only enriches in local area; while it was uniformly distributed in the corrosion product matrix of the self-developed steel. Therefore, the protection of corrosion product generated on the self-developed steel is better than that on A36 steel.

Fig. 10 shows Raman spectra of corrosion product of A36 and the self-developed steel after $240 \mathrm{~h}$ immersion test. There are peaks at 225, 293, 412, 500, 612 and $1320 \mathrm{~cm}^{-1}$ in Raman spectra of A36 steel, which are in accordance with the typical Raman spectrum of hematite $\alpha-\mathrm{Fe}_{2} \mathrm{O}_{3}$. The bands at 300, 395, 515, 645 and $670 \mathrm{~cm}^{-1}$ are associated with maghemite $\gamma$ -
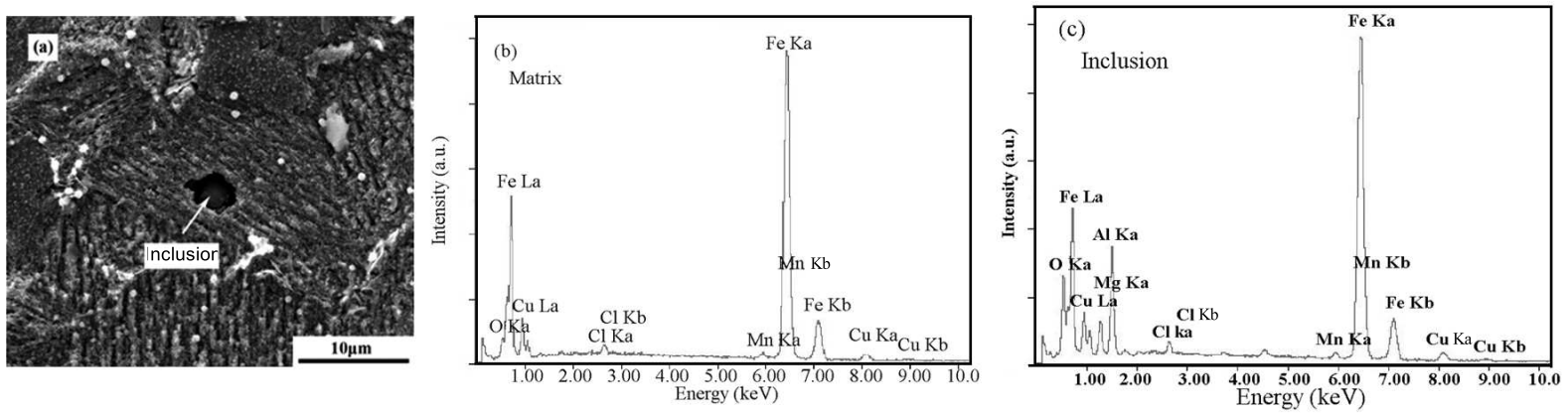

Fig. 6 SEM image of corrosion products of A36 steel after $240 \mathrm{~h}$ immersion test in $10 \mathrm{wt} . \% \mathrm{NaCl}$ solution at $(30 \pm 2)^{\circ} \mathrm{C}$ (a) and EDS spectrums of matrix (b) and inclusion (c)
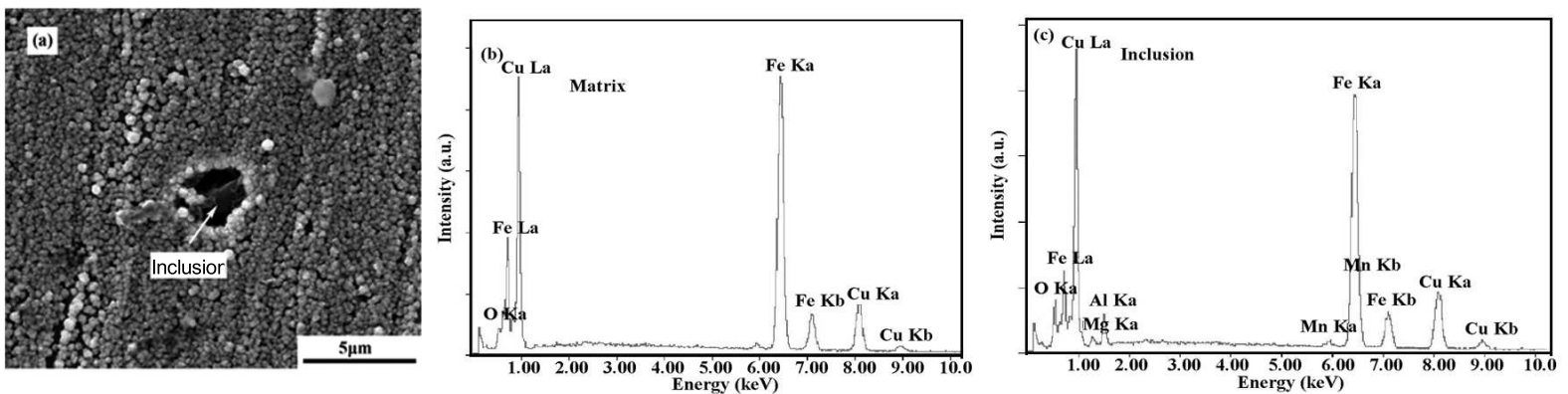

Fig. 7 SEM image of corrosion products of self-developed steel after $240 \mathrm{~h}$ immersion test in $10 \mathrm{wt} . \% \mathrm{NaCl}$ solution at $(30 \pm 2){ }^{\circ} \mathrm{C}$ (a) and EDS spectrums of matrix (b) and inclusion (c)

Table 3 Compositions (wt.\%) of matrix, corrosion product and inclusion

\begin{tabular}{ccccccccc}
\hline Specimen & Location & $\mathrm{O}$ & $\mathrm{Mg}$ & $\mathrm{Al}$ & $\mathrm{Cl}$ & $\mathrm{Mn}$ & $\mathrm{Fe}$ & $\mathrm{Cu}$ \\
\hline A36 steel & Matrix & 6.7 & - & - & 1.3 & 1.4 & 86.8 & 3.8 \\
& Inclusion & 17.2 & 6.9 & 15.8 & 0.9 & 0.9 & 55.7 & 2.5 \\
Self-developed steel & Matrix & 6.6 & - & - & - & - & 70.4 & 23.0 \\
& Inclusion & 11.2 & 2.9 & 6.3 & - & 1.0 & 55.1 & 23.5 \\
\hline
\end{tabular}




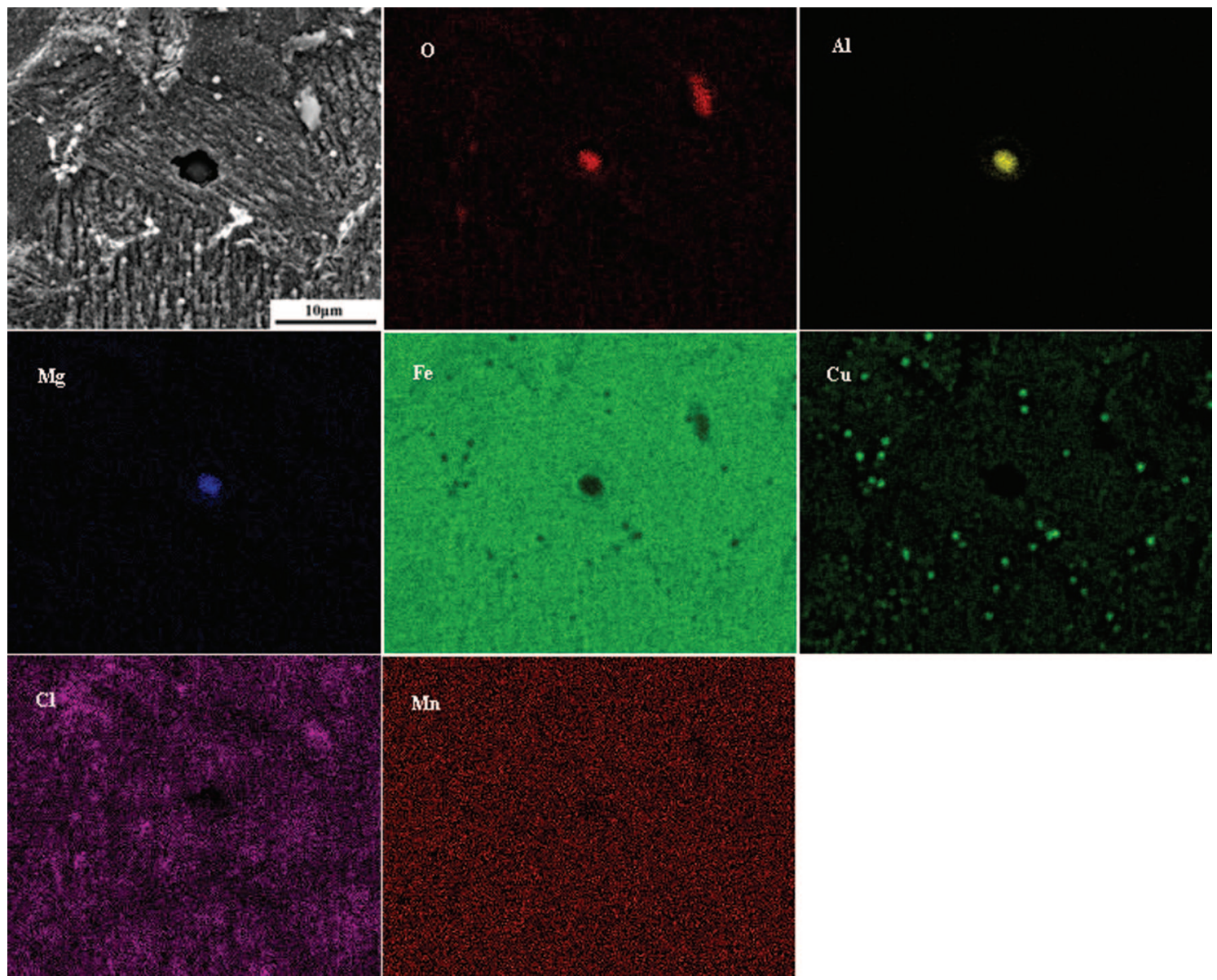

Fig. 8 SEM image and X-ray elemental maps of corrosion product of A36 steel after $240 \mathrm{~h}$ immersion test in 10 wt. $\% \mathrm{NaCl}$ solution at $(30 \pm 2){ }^{\circ} \mathrm{C}$

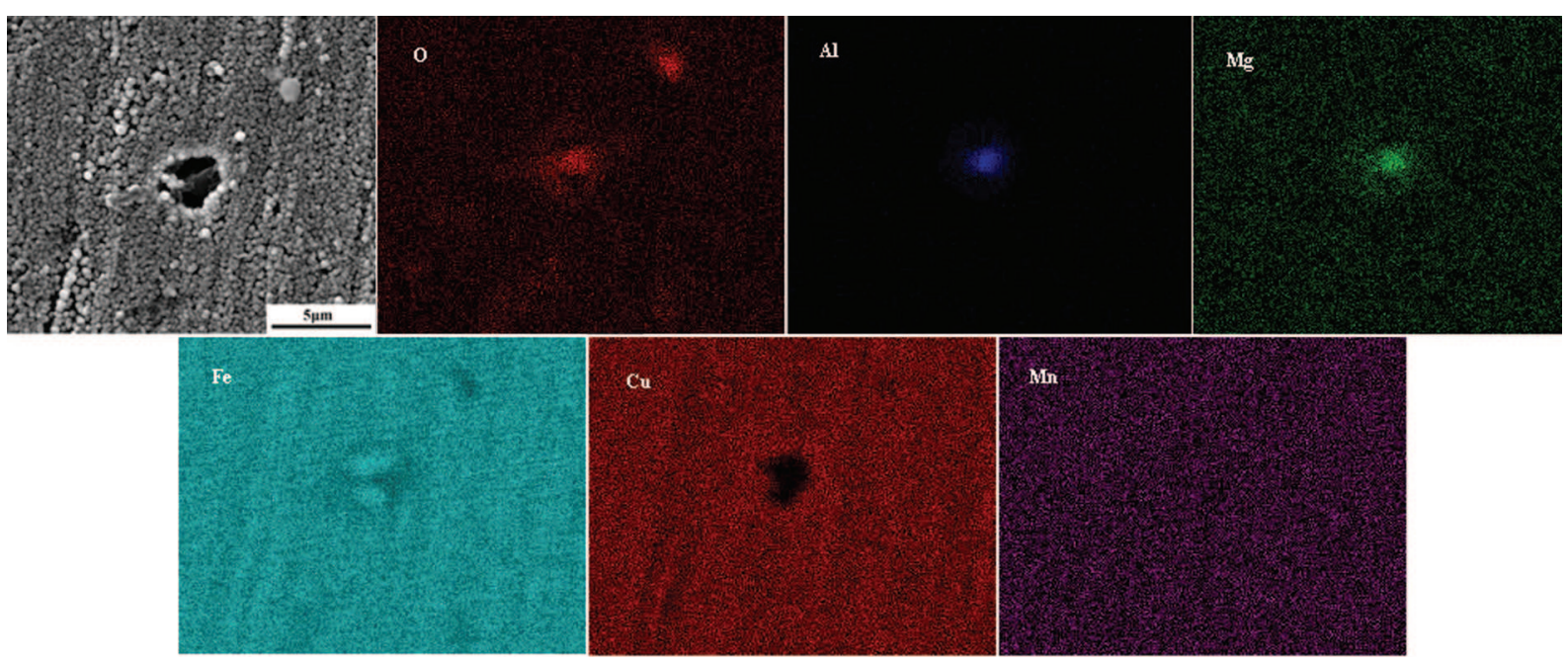

Fig. 9 SEM image and X-ray elemental maps of corrosion product of self-developed steel after $240 \mathrm{~h}$ immersion test in 10 wt. $\% \mathrm{NaCl}$ solution at $(30 \pm 2){ }^{\circ} \mathrm{C}$

$\mathrm{Fe}_{2} \mathrm{O}_{3}{ }^{[19,24]}$. This demonstrates that corrosion product of A36 steel is composed of $\alpha-\mathrm{Fe}_{2} \mathrm{O}_{3}$ and $\gamma-\mathrm{Fe}_{2} \mathrm{O}_{3}$. There are peaks at $338,385,412,480$, and $685 \mathrm{~cm}^{-1}$ in Raman spectra of the self-developed steel, which are typical Raman spectra of goethite $\alpha$-FeOOH. The bands at 320,560, 613 and $680 \mathrm{~cm}^{-1}$ are assigned to magnetite $\mathrm{Fe}_{3} \mathrm{O}_{4}{ }^{[25]}$. This demonstrates that corrosion product of the self-developed steel is composed of $\alpha-\mathrm{FeOOH}$ and $\mathrm{Fe}_{3} \mathrm{O}_{4}$

\section{Discussion}

\subsection{Transformation of $\mathrm{Fe}$}

A mechanism for the iron dissolution reaction in acidic solutions containing halide ions was proposed ${ }^{[26]}$. This mechanism suggests that iron 


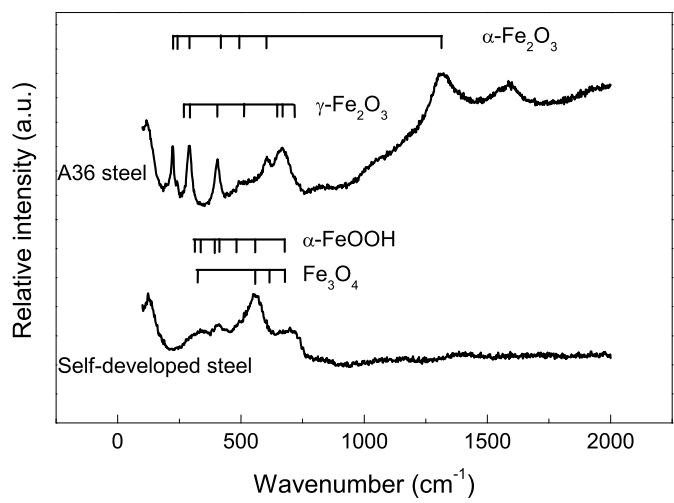

Fig. 10 Rama spectra of corrosion products formed on A36 and self-developed steel after $240 \mathrm{~h}$ immersion test in $10 \mathrm{wt} . \% \mathrm{NaCl}$ solution at $(30 \pm 2){ }^{\circ} \mathrm{C}$

dissolves through two dissolution paths in the presence of $\mathrm{Cl}^{-}$: (1) reaction path through a $\mathrm{FeOH}$ adsorbed intermediate; (2) reaction path through a $\mathrm{FeCl}$ adsorbed intermediate. The adsorption of $\mathrm{OH}^{-}$may be assumed to take place via the following steps ${ }^{[27]}$ :

$$
\begin{gathered}
\mathrm{Fe}+\mathrm{OH}^{-} \leftrightarrow \mathrm{FeOH}_{\text {ads }}^{-} \\
\mathrm{FeOH}_{\text {ads }}^{-} \leftrightarrow \mathrm{FeOH}^{+}+2 \mathrm{e} \\
\mathrm{FeOH}^{+}+\mathrm{H}_{2} \mathrm{O} \leftrightarrow \mathrm{Fe}_{\text {sol }}^{2+}+\mathrm{OH}^{-}
\end{gathered}
$$

where the subscript ads. indicate adsorbed state, the subscript sol. indicate the dissolved state.

Chloride ions are adsorbed on the iron surface during iron dissolution in the presence of $\mathrm{Cl}^{-}$. The following reactions are proposed ${ }^{[26]}$ :

$$
\begin{gathered}
\mathrm{Fe}+\mathrm{Cl}^{-} \rightarrow \mathrm{FeCl}_{\text {ads }}^{-} \\
\mathrm{FeCl}_{\text {ads }}^{-} \rightarrow \mathrm{FeCl}_{\mathrm{ads}}+e \\
\mathrm{FeCl}_{\mathrm{ads}} \rightarrow \mathrm{FeCl}_{\text {sol }}^{+}+e \\
\mathrm{FeCl}_{\text {sol }}^{+} \rightarrow \mathrm{Fe}_{\text {sol }}^{2+}+\mathrm{Cl}^{-}
\end{gathered}
$$

The competitive adsorption of $\mathrm{Cl}^{-}$and $\mathrm{OH}^{-}$is evident. The EDS results indicate that $\mathrm{Cl}$ exists in the corrosion products of A36 steel. However, there is no $\mathrm{Cl}$ in the corrosion products of the self-developed steel (Fig. 6 and Fig. 7). Therefore, it can be assumed that there is a strong interaction between $\mathrm{Cl}^{-}$and $\mathrm{Fe}$ adatoms for A36 steel. On the contrary, the adsorption of $\mathrm{OH}^{-}$prevails for the self-developed steel.

The diffusion of oxygen at the interface transforms $\mathrm{Fe}(\mathrm{OH})_{2}$ into $\mathrm{FeOOH}$ as follows:

$$
2 \mathrm{Fe}(\mathrm{OH})_{2}+\frac{1}{2} \mathrm{O}_{2} \rightarrow 2 \mathrm{FeO} \cdot \mathrm{OH}+\mathrm{H}_{2} \mathrm{O}
$$

Many researchers in the past have proposed that $\gamma-\mathrm{FeOOH}$ is initially formed, which transforms to $\mathrm{Fe}_{3} \mathrm{O}_{4}, \alpha$-FeOOH and $\gamma-\mathrm{Fe}_{2} \mathrm{O}_{3}^{[25,28]}$. It is declared that $\gamma$-FeOOH transforms to $\alpha$-FeOOH by dissolution and reprecipitation according to Misawa ${ }^{[29]}$. However, the mechanism proposed by Misawa is not the only path for the transformation of $\gamma-\mathrm{FeOOH}$ to a more stable $\delta$ - or $\alpha$-FeOOH. It has been deduced by Raman and Kuban ${ }^{[28]}$ that $\gamma-\mathrm{Fe}_{2} \mathrm{O}_{3} \cdot \mathrm{H}_{2} \mathrm{O}$ has a hexagonal arrangement of oxygen-hydroxyl layers, which is similar to many of the stable rust phases, such as $\alpha, \beta$ and $\delta$-FeOOH. Thus, $\gamma$-FeOOH with a cubic stacking arrangement of layers containing oxygenhydroxyl ions transforms topologically (requiring only slight readjustment of atoms, not requiring long-range diffusion-dependent nucleation and growth processes) to $\gamma-\mathrm{Fe}_{2} \mathrm{O}_{3} \cdot \mathrm{H}_{2} \mathrm{O}$ with a hexagonal stacking arrangement of these layers, which in turn transforms easily to $\delta$-FeOOH or $\alpha$-FeOOH. The Raman spectra results has revealed that corrosion product of self-developed steel is composed of $\alpha$-FeOOH and $\mathrm{Fe}_{3} \mathrm{O}_{4}$. The formation of such stable and protective rust layer will be in favor of improvement of corrosion resistance.

\subsection{Effect of $\mathrm{Cu}$}

It has been declared that copper ions dissolved during corrosion reaction could be re-precipitated on the surface of steel and served as an efficient cathodic site. This mechanism is applicable when $\mathrm{pH}$ value of the local electrolyte is quite low; especially in the presence of chloride ions ${ }^{[25]}$. In this work, corrosion electrolyte is 10 wt.\% $\mathrm{NaCl}$ solutions with $\mathrm{pH}$ value of 0.85 . And it has been found that $\mathrm{Cu}$ exist in rust layer of A36 and the self-developed steels, as shown in Fig. 6 and Fig. 7 and Table 3. It can be seen that there are 3.8 at.\% $\mathrm{Cu}$ in rust layer of A36 steel and 23.0 at. $\% \mathrm{Cu}$ in rust layer of the self-developed steel. The content of $\mathrm{Cu}$ in rust layer of both steels is much higher than that in steel matrix. This demonstrates that a $\mathrm{Cu}$ enriched layer forms on the surface of steels, which can be explained by the preferential dissolution and redeposition process of copper. In an acid solution, both $\mathrm{Fe}$ and $\mathrm{Cu}$ dissolve, however the dissolved $\mathrm{Cu}$ re-deposits with the form of re-crystallized $\mathrm{Cu}$ and $\mathrm{Cu}$ oxides ${ }^{[30,31]}$. The mechanisms of the selective dissolution and re-deposition processes of $\mathrm{Cu}$ in low alloy steel can be outlined as follows:

(1) At the initial stage of corrosion, the steel surface is mainly composed of Fe with a small amount of $\mathrm{Cu}$ near the solution/metal interface.

(2) When Fe dissolves, Cu may subsequently be away from the metal surface as steel does not have a continuous $\mathrm{Cu}$ network. Therefore, the preferential dissolution of $\mathrm{Cu}$ occurs along the continuous paths of less noble atoms ${ }^{[32]}$.

(3) As soon as $\mathrm{Cu}$ is separated from the surrounding $\mathrm{Fe}, \mathrm{Cu}$ dissolves to $\mathrm{Cu}^{2+}$ coupling with reduction of the dissolved oxygen.

(4) $\mathrm{Cu}^{2+}$ acts as an oxidant in $\mathrm{Fe}, \mathrm{H}_{2} \mathrm{O}$ and $\mathrm{O}_{2}$ system. Therefore, a proportion of $\mathrm{Cu}^{2+}$ will reduce (with consumption of the electrons produced by oxidation of the $\mathrm{Fe}$ ) and then re-deposit onto the substrate, which is called $\mathrm{Cu}$ plating. And the amount of $\mathrm{Cu}$ plating should increases as the $\mathrm{Cu}^{2+}$ concentration 
increases $^{[33]}$.

(5) The re-deposited $\mathrm{Cu}$ will be precipitated as re-crystallized $\mathrm{Cu}$ and $\mathrm{Cu}$ oxides. The selective dissolution and redeposition process will repeat until the $\mathrm{Cu}$ enriched layer is stabilized ${ }^{[31]}$.

Because the $\mathrm{Cu}$ composition (23.0 at.\%) in rust layer of the self-developed steel is much more than that of A36 steel (3.8 at.\%), the distribution of $\mathrm{Cu}$ in rust layer of the self-developed steel is more homogeneous and continuous, as shown in Fig. 8 and Fig. 9. The continuous formation of $\mathrm{Cu}$ enrichment layer may give birth to a higher number of sites which are in favor of the adsorption reaction of the protective corrosion products but have an adverse effect on the overall charge transfer process. The accumulation of copper would diminish the iron dissolution by blocking the active points in the lattice. Therefore, the copper enrichment layer decreases the anodic dissolution rate by a blocking mechanism and a screening mechanism $^{[33]}$.

\section{Conclusions}

The self-developed steel has superior corrosion resistance and can be directly applied to COT of crude oil tankers without the protection of coating. The average corrosion mass loss rate of the self-developed steel is only $0.22 \mathrm{~mm} / \mathrm{a}$, which is $1 / 5$ of the accepted criterion $(v \leq 1 \mathrm{~mm} / \mathrm{a})$ for corrosion resistance steels, according to IMO MSC 87/26/Add. 1 Annex 3 MSC. 289 (87).

The excellent corrosion resistance of the selfdeveloped steel could be attributed to its low carbon content $(0.08$ wt.\%), high alloy element content $(\mathrm{Cu})$ and fine microstructure $(\mathrm{F} / \mathrm{B})$. Consequently, a protective rust layer grows on the surface of the selfdeveloped steel, consisting of $\alpha-\mathrm{FeOOH}, \mathrm{Fe}_{3} \mathrm{O}_{4}$ and a continuous $\mathrm{Cu}$ enrichment layer.

\section{Acknowledgements}

This work was financial supported by the Fundamental Research Funds for the Central Universities (No.FRFPT-12-144A) and the National Natural Science Foundation of China (Nos.51171025 and 51271023) and National network of Field Observation \& Scientific Research on Material Environmental Corrosion.

\section{REFERENCES}

[1] P. Tscheliesnig, in: Proc. of the $16^{\text {th }}$ World Conference on Nondestructive Testing, Montreal, Canada, 30 Aug.-3 Sept., 2004.

[2] Ship research panel 242, Ship Research Summary Report No.431, Tokyo, JSRA, 2002.

[3] Y. Inohara, T. Komori, K. Kyono, K. Ueda, S. Suzuki and H. Shiomi, in: Proc. of the International Symposium on Shipbuiding Technology, Osaka, Japan, 6-7 Sept., 2007.

[4] K Kashima, Y Tanino, S Kubo, A. Inami and H.
Miyuki, in: Proc. of the International Symposium on Shipbuilding Technology, Osaka, Japan, 6-7 Sept., 2007.

[5] K. Katoh, S. Imai, T. Yasunaga, H. Miyuki, Y. Yamane, H. Ohyabu, Y. Kobayashi, M. Yoshikawa and Y. Tomita, in: Proc of the World Maritime Technology Conference, San Francisco, CA, 17-20 Oct., 2003.

[6] S. Sakashita, A. Tatsumi, H. Imamura and H. Ikeda, in: Proc. of the International Symposium on Shipbuilding Technology, Osaka, Japan, 6-7 Sept., 2007.

[7] Y. Tanino, S. Kudo, A. Inami, K. Kashima and H. Miyuki, in: Proc. of the Asia Steel International Conference, Fukuoka, Japan, 9-11 May, 2006.

[8] IMO, in: Proc. of the Sub Committee on Ship Design and Equipment DE 51/INF.4, London, 16 Nov., 2007.

[9] H. Shiomi, M. Kaneko, K. Kashima, H. Imamura and T. Komori, in: Proc. of the TSCF 2007 Shipbuilders Meeting, Daejeon, Korea, 24-25 Oct., 2007.

[10] X.H. Hao, J.H. Dong, J. Dong, W. Ke, C.G. Wang, X.L. Xu and Q.B. Ye, Acta Metall. Sin. 48 (2012) 534. (in Chinese)

[11] J.W. Yang, J. Xu, J.P. Cao, H. Liu, Y.Q. Chen and J. Zhang, Corros. Prot. 33 (2012) 39.

[12] X.Y. Feng, Y.C. Qi, Y. Peng, Z.L. Tian and Q.H. Xue, J. Iron Steel Res. 24 (2012) 44.

[13] IMO, in: Proc of the Maritime Safety Committee on its eighty-seventh session Annex 3 MSC.289 (87), London, 30 June, 2010.

[14] R.A. Antunes, I. Costa and D.L.A. de Faria, Mater. Res. 6 (2003) 403.

[15] K. Xiao, C.F Dong, X.G. Li and F.H. Wang, J. Iron Steel Res. Int. 15 (2008) 42.

[16] D. Clover, B. Kinsella, B. Pejcic and R. de Marco, J. Appl. Electrochem. 35 (2005) 139.

[17] S. Imai, K. Katoh, Y. Funatsu, M. Kaneko, T. Matsubara, H. Hirooka and H. Sato, in: Proc of the Shipbuilding Technology ISST 2007, Osaka, Japan, 6-7 Sept., 2007.

[18] N.D. Nam, M.J. Kim, Y.W. Jang and J.G. Kim, Corros. Sci. 52 (2010) 14.

[19] C.N. Cao, Electrochim. Acta 35 (1990) 831.

[20] C.N. Cao, Electrochim. Acta 35 (1990) 83.

[21] C.N. Cao and J.Q. Zhang, An Introduction to Electrochemical Impedance Spectroscopy , Science Press, Beijing, 2003, pp. 181-190.

[22] M. Stern and A.L. Geary, J. Electrochem. Soc. 104 (1957) 56.

[23] E. McCafferty, Corros. Sci. 47 (2005) 3202.

[24] L.J. Oblonsky and T.M. Devine, J. Electrochem. Soc. 144 (1997) 1252.

[25] J.K. Singh and D.D.N. Singh, Corros. Sci. 56 (2012) 129.

[26] M. Itagaki, M. Tagaki and K. Watanbe, Electrochim. Acta 41 (1996) 1201.

[27] L. Felloni, Corros. Sci. 8 (1968) 133.

[28] A. Raman and B. Kuban, Corrosion 44 (1988) 483.

[29] T. Misawa, K. Hashimoto and S. Shimodaira, Corros. Sci. 14 (1974) 131.

[30] S.S. El-Egamy, Corros. Sci. 50 (2008) 928.

[31] J.H. Hong, S.H. Lee, J.G. Kim and J.B. Yoon, Corros. Sci. 54 (2012) 174.

[32] H. Kaiser, Corros. Sci. 34 (1993) 683.

[33] A.A. Hermas, K. Ogura and T. Adachi, Electrochim. Acta 40 (1995) 837. 